\title{
Correction to: A compiler framework for the reduction of worst-case execution times
}

\author{
Heiko Falk ${ }^{1}$ - Paul Lokuciejewski ${ }^{1}$
}

Published online: 28 June 2019

(c) The Author(s) 2019

\section{Correction to: Real-Time Systems (2010) 46: 251-300 https://doi.org/10.1007/s11241-010-9101-x}

The article A compiler framework for the reduction of worst-case execution times, written by Heiko Falk and Paul Lokuciejewski, was originally published electronically on the publisher's internet portal (currently SpringerLink) on 22 July 2010 without open access.

With the author(s)' decision to opt for Open Choice the copyright of the article changed on June 2019 to (C) The Author(s) 2019 and the article is forthwith distributed under the terms of the Creative Commons Attribution 4.0 International License (http:// creativecommons.org/licenses/by/4.0/), which permits use, duplication, adaptation, distribution and reproduction in any medium or format, as long as you give appropriate credit to the original author(s) and the source, provide a link to the Creative Commons license and indicate if changes were made.

Open Access This article is distributed under the terms of the Creative Commons Attribution 4.0 International License (http://creativecommons.org/licenses/by/4.0/), which permits use, duplication, adaptation, distribution and reproduction in any medium or format, as long as you give appropriate credit to the original author(s) and the source, provide a link to the Creative Commons license, and indicate if changes were made.

Publisher's Note Springer Nature remains neutral with regard to jurisdictional claims in published maps and institutional affiliations.

The original article can be found online at https://doi.org/10.1007/s11241-010-9101-x.

$\bowtie$ Heiko Falk

Heiko.Falk@tu-dortmund.de

Paul Lokuciejewski

Paul.Lokuciejewski@tu-dortmund.de

1 Computer Science 12, TU Dortmund University, 44221 Dortmund, Germany 